\title{
Effects of giving a fat-free diet for up to 10 weeks on the male weanling rat
}

\author{
BY JENS G. NøRBY \\ Department of Biochemistry, University of Arhus, Arhus C, Denmark \\ (Received 2 September 1964-Accepted 23 October 1964)
}

When weanling rats are reared on a fat-free diet for about Io weeks they develop, as originally shown by Burr \& Burr (1929), certain signs of a nutritional deficiency. The signs can be cured or prevented by the inclusion of essential fatty acids (EFA), as linoleic acid, in the diet and the condition is therefore termed EFA deficiency.

The weanling male rat has been used extensively in studies concerning EFA deficiency. In this animal the deficiency is characterized by a number of clinical signs such as lower weight gain, scaly skin, partial necrosis of the tail, increased water consumption. Besides this, the fatty acid pattern in the tissues is different from that in the normal rat. Generally, the concentrations of di-, tetra-, penta- and hexaenoic acids are lower, whereas the concentrations of trienoic and monoenoic acids with 16-18 carbon atoms are higher in deficient than in normal animals (Caster \& Holman, 196r; Mohrhauer \& Holman, I963).

The early changes in the polyenoic fatty acid pattern in the weanling rat fed on an EFA-free diet have not been studied previously. Aaes-Jørgensen \& Holman (1958) have demonstrated that the changes in testes polyenes are confined to the first 6 weeks of feeding after which the concentrations remain approximately constant. Brenner, Mercuri \& De Tomás (1962) found, in accordance with this, that the polyenoic acid concentration of heart tissue was the same after $\mathbf{I} 3$ weeks as after 8 weeks of feeding, and that the concentration of dienoic acid in liver after 8 weeks was very nearly nil.

In experiments with day-old chicks, Machlin (I96I) observed that EFA deficiency is reflected in the fatty acid pattern of heart and liver after 1-2 weeks, and Holman (1956) has published a depletion curve for mice showing a rapid fall in linoleic acid content during the ist week on the deficient diet. The change in linoleic acid content (percentage of total fatty acids (TFA)) in depot fat of weanling mice fed on a fat-free diet has been studied by Tove $\&$ Smith (1959) for 25 days. It appeared that the linoleic acid concentration in relation to time followed the equation of a first-order reaction.

A quantitative description of the changes in polyenoic acid concentrations in plasma, heart and liver during the first to weeks of EFA deficiency of rats given deficient diets from weaning is given in the present paper. Further, the weight of body, heart and liver, as well as the dermal signs, are reported. 


\section{EXPERIMENTAL}

Animals and diets. Forty-two weanling, 21-day-old, male albino rats (body-weight 34-59 g) were divided into ten groups. Care was taken that rats from the same litter were placed in different groups. The number of animals per group, the mean group weight and the length of the dietary period are shown in Table 1 . Seven groups $(\mathrm{I}, 2,3,4,6,8$ and $\mathrm{IO}$ ) were given a fat-free diet (Table 2$)$ ad lib. for $\mathrm{I}-\mathrm{Io}$ weeks and two groups ( $22 \frac{1}{2}$ and $\mathrm{C} 6$ ) were given for $2 \frac{1}{2}$ or 6 weeks a commercial chick feed, Karatgryn (Karensmølle, Århus), containing $c .3500 \mathrm{kcal} / \mathrm{kg}$ and $2.5 \%$ fatty acids of which $40 \%$ is dienoic, $0.9 \%$ trienoic and $1.5 \%$ tetraenoic acid. Karatgryn has been used as the stock diet in this laboratory for 7 years and seems to satisfy entirely the nutritional requirements of the rat.

The rats were weighed and inspected for deficiency signs at weekly intervals. The

Table I. Number of rats, mean body-zveight at weaning, and length of experimental period for each group

\begin{tabular}{ccccl} 
Group no. & $\begin{array}{c}\text { No. of } \\
\text { rats }\end{array}$ & $\begin{array}{c}\text { Weight at } \\
\text { weaning } \\
(\mathrm{g})\end{array}$ & $\begin{array}{c}\text { Weeks on } \\
\text { diet }\end{array}$ & \multicolumn{1}{c}{ Diet } \\
0 & 5 & $43 \cdot 2$ & 0 & Mother's milk \\
I & 4 & $46 \cdot 8$ & I & Fat-free \\
2 & 5 & $46 \cdot 6$ & 2 & Stock \\
C $2 \frac{1}{2}$ & 3 & $44 \cdot 0$ & $2 \frac{1}{2}$ & Fat-free \\
3 & 4 & $45 \cdot 5$ & 3 & \\
4 & 5 & $43 \cdot 4$ & 4 & \\
6 & 4 & $42 \cdot 0$ & 6 & Stock \\
C 6 & 3 & $41 \cdot 7$ & 6 & Fat-free \\
8 & 5 & $42 \cdot 2$ & 8 & \\
I0 & 4 & $4 I \cdot 8$ & 10 &
\end{tabular}

Standard errors of mean weaning weights $(\mathrm{g}): \pm 3.9$ (three rats), \pm 3.4 (four rats), $\pm 3 \cdot 0$ (five rats).

Table 2. Composition of fat-free diet

$\begin{array}{lcc} & \begin{array}{c}\text { Calorie } \\ \text { contribution }\end{array} \\ \text { Ingredient } & \% & (\%) \\ \text { Casein* } & 20 & \mathbf{2 1} \\ \text { Sucrose } & 74.5 & \mathbf{7 9} \\ \text { Salts† } & 5 & - \\ \text { Vitamins } \ddagger & 0.5 & -\end{array}$

* Commercial casein (acid-precipitated) containing about $0.5 \%$ of fatty acids was extracted with $96 \%$ ethanol in a Soxhlet apparatus for $\mathrm{I} 2 \mathrm{~h}$ and dried. The total fatty acid content thereby decreased to about $0.04 \%$, corresponding to $c .0 . \mathrm{g} / \mathrm{kg}$ diet. The dienoic acid concentration was about $2 \%$ of total fatty acids.

$\uparrow$ Osborne-Mendel salt mixture prepared as described by Hawk \& Bergeim (1937).

I Mixture contained $(\mathrm{mg} / \mathrm{g})$ : thiamine hydrochloride $2 \mathrm{I}$, riboflavine $7 \cdot 9$, nicotinamide 17 , calcium pantothenate 21, pyridoxine hydrochloride 7.9 , biotin 0.6 , folic acid 3 , $p$-aminobenzoic acid 173 , inositol 346 , choline chloride 400 , cyanocobalamin 0.0095 , menaphthone sodium bisulphite (vitamin $\mathrm{K}$ ) 2.6. A mixture of fat-soluble vitamins dissolved in peroxide-free diethyl ether was sprayed over the diet, providing ( $\mathrm{mg} / \mathrm{kg}$ diet): vitamin A palmitate 5, ergocalciferol 0.1 , tocopherol 100 and arachis oil 15. 
tail, forelegs, hindlegs and fur were scored separately for signs of deficiency according to the following scale:

$\begin{array}{cl}\text { Score } & \text { Deficiency signs } \\ \text { I } & \text { None } \\ & \text { Tail, slightly scaly; feet, slightly scaly; fur, appears thin at } \\ \text { several spots } & \text { Tail, scaly; feet and legs, scaly; fur, thin all over the body } \\ 2 & \text { Tail, very scaly, ridged; feet and legs, very scaly; } \\ 3 & \text { complete loss of fur at several spots }\end{array}$

The four scores were added up and the result was taken as the dermal score of the animal.

The rats were killed, and plasma, liver and heart obtained as described below. After I $2 \mathrm{~h}$ fast, $5 \mathrm{mg}$ Nembutal-sodium (Abbott Laboratories Ltd)/ $100 \mathrm{~g}$ rat were injected parenterally. The thorax was opened and as much blood as possible removed from the rat by heart puncture with a heparinized syringe. Then heart and liver were removed and weighed immediately. The organs and plasma were stored at $-20^{\circ}$ until analysed.

Analytical methods. Isolation and titration of fatty acids, as well as determination of polyenoic acids by alkaline isomerization (Herb \& Riemenschneider, 1953) were carried out as described previously (Nørby, I96I). In the calculations of the polyenoic acid concentrations the spectral constants for eicosatrienoic acids $(85 \%, 8$, II, I4- and I $5 \% 5,8$, II-eicosatrienoic acid) published by Montag, Klenk, Hayes \& Holman (1957) have been used: $k(\mathrm{I} \mathrm{g} / 1 .)_{233}=59 \cdot 5$ and $k_{268}=72 \cdot \mathrm{I}$. Expressed as $k$ (I m-equiv./1.) they become $k_{233}=18.23, k_{268}=22 \cdot 01$. When these constants are used instead of those for linolenic acid usually employed, the polyenoic acid concentrations in equiv./100 equiv. TFA can be calculated from the following equations, where $k^{\prime}=E$ ( I m-equiv. TFA/l.):

$$
\begin{aligned}
& \text { Hexaene }=\mathrm{II} \cdot 34 k_{6}^{\prime}-0 \cdot 669 k_{5}^{\prime}, \\
& \text { Pentaene }=4 \cdot 7 k_{5}^{\prime}-4 \cdot 89 k_{6}^{\prime}, \\
& \text { Tetraene }=5 \cdot 42 k_{4}^{\prime}-5 \cdot 14 k_{5}^{\prime}-0.92 \mathrm{I} k_{6}^{\prime}, \\
& \text { Triene }=4 \cdot 54 k_{3}^{\prime}-3^{\cdot 61} k_{4}^{\prime}+\mathrm{I} \cdot 82 \mathrm{I} k_{5}^{\prime}-6 \cdot 3 \mathrm{I} k_{6}^{\prime}, \\
& \text { Diene }=3^{\cdot} \cdot 8 \mathrm{~g} k_{2}^{\prime}-3^{\cdot} 22 k_{3}^{\prime}+0.013 k_{4}^{\prime}-0.58 \mathrm{I} k_{5}^{\prime}+0.679 k_{6}^{\prime} .
\end{aligned}
$$

These empirical equations are based on spectral constants determined by Montag et al. (1957) and Herb \& Riemenschneider (1953) and not by me. Therefore, a systematic error in the determination may be introduced, e.g. if there was a small difference between my isomerization procedure and that of Montag et al. (1957) or Herb \& Riemenschneider (1953). Apparently it was so in the determination of dienoic (Fig. 3) and trienoic (Fig. 4) acids, for which negative concentrations were found in some instances.

In the calculation of the relative concentration of dienoic acid (see p. 220), therefore a value of 3 equiv./roo equiv. TFA was added to the observed values for plasma concentrations and a value of 2 equiv./10o equiv. TFA was added to the observed values for concentrations of dienoic acid in heart and liver of both the controls and the deficient animals. 
Cholesterol was determined on a portion of the unsaponifiable extract as described by Hauge \& Nicolaysen (1958).

Duplicate determinations of all the lipids mentioned were made on plasma, heart and liver from each animal individually, except for the plasma samples from animals in group 0 . With these samples, since one heart puncture was unsuccessful and only small amounts of blood were obtained from the other animals, the plasma from two animals was pooled, so that only two samples from group o have been analysed.

\section{RESULTS}

The term deficient is used for rats that received the fat-free diet (groups I, 2, 3, 4, 6, 8 and 10), whereas the rats in group o, $\mathrm{C} 2 \frac{1}{2}$ and $\mathrm{C} 6$ are termed controls.

Dermal signs. The mean dermal score (Table 3 ) for rats fed on a fat-free diet increased proportionally with time during the first 6 weeks and was significantly higher than that of the controls after 2 weeks.

Table 3. Dermal score for rats fed on a fat-free diet $(F F)$ for up to to weeks or on the stock diet $(C)$ for up to 6 weeks after weaning

\begin{tabular}{|c|c|c|c|c|c|}
\hline \multirow{2}{*}{$\begin{array}{l}\text { Weeks } \\
\text { on diet }\end{array}$} & \multicolumn{2}{|c|}{ No. of animals } & \multicolumn{2}{|c|}{ Dermal score* } & \multirow{2}{*}{$\begin{array}{c}\text { Dermal } \\
\text { score/week } \\
F F\end{array}$} \\
\hline & $F F$ & $C$ & $F F$ & $C$ & \\
\hline 0 & - & 42 & - & $\circ$ & - \\
\hline $\mathbf{I}$ & $3 \mathrm{I}$ & 6 & $0.39 \pm 0.15$ & $0.17 \pm 0.17$ & 0.39 \\
\hline 2 & 27 & 6 & $2 . \mathrm{II} \pm 0.23$ & $I \cdot I 7 \pm 0.21$ & I.06 \\
\hline 3 & 22 & 3 & $2.73 \pm 0.29$ & $0.17 \pm 0.17$ & 0.91 \\
\hline 4 & I8 & 3 & $3.78 \pm 0.30$ & $0.33 \pm 0.32$ & 0.94 \\
\hline 5 & 13 & 3 & $4 \cdot 54 \pm 0.18$ & $0.17 \pm 0.17$ & 0.91 \\
\hline 6 & 13 & 3 & $5.08 \pm 0.21$ & $0.50 \pm 0.34$ & 0.83 \\
\hline 7 & 9 & - & $5 \cdot 44 \pm 0.34$ & 二 & 0.77 \\
\hline 8 & 9 & - & $6.22 \pm 0.40$ & - & 0.78 \\
\hline 9 & 4 & - & $7.00 \pm 0.91$ & - & 0.77 \\
\hline Io & 4 & 一 & $7 \cdot 25 \pm I \cdot I I$ & - & 0.73 \\
\hline
\end{tabular}

Growth. The mean growth rate, as measured by body-weight, was lower for deficient than for control animals (Fig. I). When liver and heart weights are considered, it appears that the gain in weight of these organs was not affected by the diet (Fig. 2). Consequently it was found that liver and heart weights expressed as percentages of body-weights were higher for deficient than for control animals 6 weeks after weaning: liver of controls $=3.49 \% \pm 0.15$, liver of deficient animals $=4 \cdot 12 \% \pm 0.20$, heart of controls $=0.254 \% \pm 0.003$, heart of deficient animals $=0.340 \% \pm 0.022$.

Cholesterol and total fatty acids (TFA) (Table 4). The concentration of cholesterol in plasma in the control animals decreased with time, whereas it was independent of time in the deficient animals. After 6 weeks the latter had a plasma cholesterol concentration which was about twice that of the controls. Plasma TFA concentrations were independent of the length of the dietary period for both control and deficient animals.

In the liver of the controls the concentration of cholesterol and TFA did not change with time. The deficient animals, however, showed an accumulation of both chole- 
sterol and TFA in liver after 6 weeks on the diet, and the concentrations for group Io were more than twice those for group $\mathrm{C} 6$.

The concentrations of cholesterol and TFA in the heart were equal for control and deficient animals. The cholesterol concentration showed a pronounced fall during the first 3 weeks, but the concentration of TFA was independent of time.

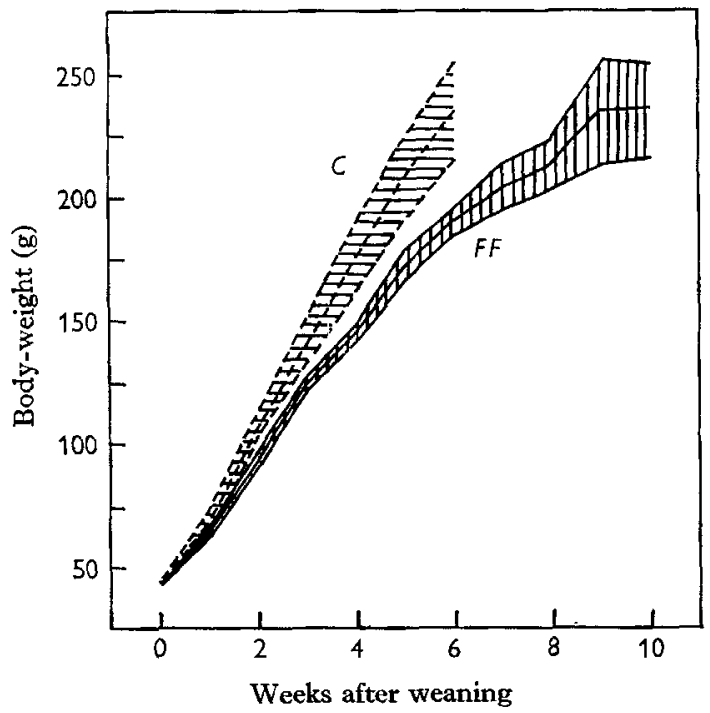

Fig. I. Mean body-weight with its standard error of rats fed on a fat-free diet $(F F)$ for up to Io weeks or on the stock diet $(C)$ for up to 6 weeks after weaning.
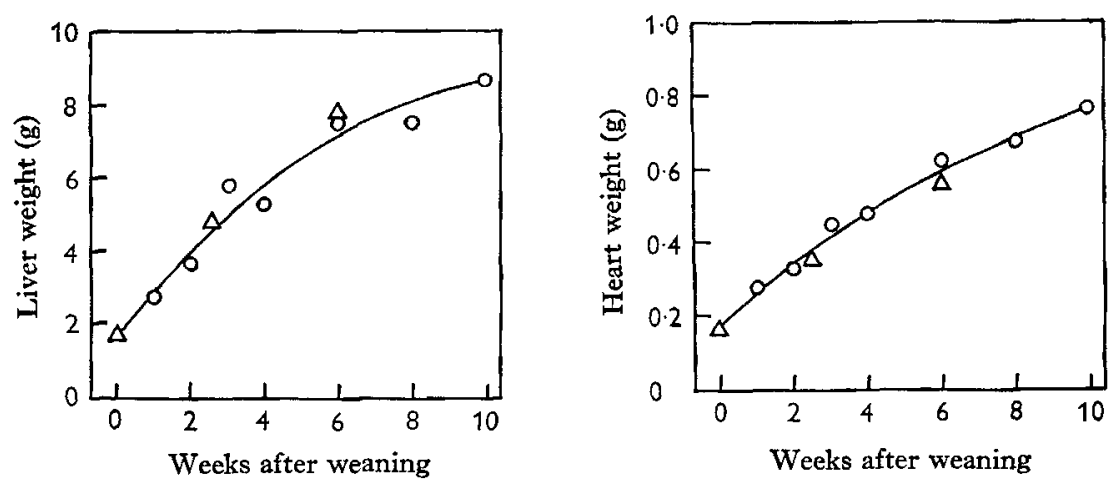

Fig. 2. Mean weights of livers and hearts of rats fed on a fat-free diet $(O)$ for up to ro weeks or on the stock diet $(\triangle)$ for up to 6 weeks after weaning.

Polyenoic acids. The group mean for the concentrations (equiv./10o equiv. TFA) of di-, tetra-, penta- and hexa-enoic acids in plasma, liver and heart are presented in Fig. 3. The ranges of the standard error of the mean corresponding to the values in Fig. 3 are given in Table 5. The extrapolations of the control curves for plasma and heart were performed on the basis of earlier observations on male rats of the same strain (Nørby, 1965). These animals had received the stock diet for 24 and 32 weeks 
after weaning and the polyenoic acid concentrations in their plasma and heart are given in Table 6 .

As for the control animals, the dienoic acid concentration increased with time, and in the heart it almost doubled within the first 2 weeks. The concentrations of the other polyenoic acids (Fig. 3), except perhaps pentaenoic acid in the liver, exhibited a slight fall during the first weeks after weaning.

The effect of giving the fat-free diet instead of the stock diet was apparent after

Table 4. Concentrations of cholesterol and total fatty acids in plasma, liver and heart of rats fed on a fat-free diet for up to 10 weeks or on the stock diet for up to 6 weeks after weaning

\begin{tabular}{|c|c|c|c|c|c|c|c|}
\hline \multirow[b]{2}{*}{ Group } & \multirow{2}{*}{$\begin{array}{l}\text { No. of } \\
\text { animals }\end{array}$} & \multicolumn{3}{|c|}{ Cholesterol (mg/roo g) } & \multicolumn{3}{|c|}{ Total fatty acids (m-equiv. $/ \mathrm{kg}$ ) } \\
\hline & & Plasma & Liver & Heart & Plasma & Liver & Heart \\
\hline$\circ$ & 5 & 84 & 242 & 205 & $6 \cdot 1$ & I33 & 79 \\
\hline $\begin{array}{l}\text { I } \\
2\end{array}$ & $\begin{array}{l}4 \\
5\end{array}$ & $\begin{array}{l}95 \\
91\end{array}$ & $\begin{array}{l}306 \\
276\end{array}$ & $\begin{array}{l}192 \\
187\end{array}$ & $\begin{array}{l}12.5 \\
10.1\end{array}$ & $\begin{array}{l}130 \\
107\end{array}$ & $\begin{array}{l}82 \\
86\end{array}$ \\
\hline $\mathrm{C}_{2 \frac{1}{2}}$ & 3 & 69 & 316 & 169 & 10.5 & 168 & 80 \\
\hline $\begin{array}{l}3 \\
4 \\
6\end{array}$ & $\begin{array}{l}4 \\
5 \\
4\end{array}$ & $\begin{array}{l}95 \\
97 \\
93\end{array}$ & $\begin{array}{l}346 \\
315 \\
412\end{array}$ & $\begin{array}{l}159 \\
146 \\
151\end{array}$ & $\begin{array}{l}14 \cdot 1 \\
11 \cdot 8 \\
10 \cdot 4\end{array}$ & $\begin{array}{l}171 \\
122 \\
191\end{array}$ & $\begin{array}{l}78 \\
81 \\
91\end{array}$ \\
\hline C 6 & 3 & 57 & 261 & 150 & $7 \cdot 6$ & 125 & 74 \\
\hline $\begin{array}{r}8 \\
\text { I0 }\end{array}$ & $\begin{array}{l}5 \\
4\end{array}$ & $\begin{array}{l}97 \\
84\end{array}$ & $\begin{array}{l}498 \\
610\end{array}$ & $\begin{array}{l}\text { I34 } \\
137\end{array}$ & $\begin{array}{l}12 \cdot 2 \\
11 \cdot 3\end{array}$ & $\begin{array}{l}186 \\
270\end{array}$ & $\begin{array}{l}83 \\
86\end{array}$ \\
\hline $\begin{array}{l}\text { Standard } \\
\text { errors of } \\
\text { means }\end{array}$ & $\begin{array}{l}3 \\
4 \\
5\end{array}$ & $\begin{array}{l}8 \cdot 4 \\
7 \cdot 3 \\
6 \cdot 5\end{array}$ & $\begin{array}{l}40 \\
35 \\
31\end{array}$ & $\begin{array}{l}16 \\
14 \\
12\end{array}$ & $\begin{array}{l}\mathbf{I} \cdot 8 \\
\mathbf{I} \cdot 5 \\
\mathbf{I} \cdot 4\end{array}$ & $\begin{array}{l}20 \\
17 \\
16\end{array}$ & $\begin{array}{l}6 \cdot 9 \\
6 \cdot 0 \\
5 \cdot 4\end{array}$ \\
\hline
\end{tabular}

Table 5: Approximate standard errors of the mean concentrations of polyenoic acids in the plasma, liver and heart for all groups of rats

\begin{tabular}{|c|c|c|c|c|}
\hline Fatty acid & Term & Plasma & Liver & Heart \\
\hline Dienoic & Equiv./roo equiv. TFA & 0.7 & 0.6 & 0.8 \\
\hline Trienoic & & I.5 & I.4 & $I \cdot 0$ \\
\hline Tetraenoic & & $1 \cdot 3$ & I. & I.O \\
\hline Pentaenoic & Percentage of group mean* & 24 & 16 & 13 \\
\hline Hexaenoic & & 17 & 15 & II \\
\hline
\end{tabular}

TFA, total fatty acids.

* For pentaenoic and hexaenoic acids the standard error was roughly proportional to the mean.

Table 6. Mean values with their standard errors for polyenoic acid concentrations (equiv./ 100 equiv. total fatty acids) in plasma and heart of adult male rats fed on stock diet for 24 or 32 weeks from weaning

\begin{tabular}{|c|c|c|c|c|}
\hline \multirow[b]{2}{*}{ Fatty acid } & \multicolumn{2}{|c|}{ Plasma } & \multicolumn{2}{|c|}{ Heart } \\
\hline & 24 weeks & 32 weeks & 24 weeks & 32 weeks \\
\hline Dienoic & $22 \cdot 2 \pm 0 \cdot 3$ & $22 \cdot 0 \pm 0.8$ & $20.4 \pm 0.4$ & $2 I \cdot 2 \pm 0.6$ \\
\hline Trienoic & $2 \cdot 2 \pm 0.5$ & $I \cdot 1 \pm 0 \cdot 3$ & $0.0 \pm 0.4$ & $-0.6 \pm 0.2$ \\
\hline Tetraenoic & $17.3 \pm 0.6$ & $15.0 \pm 0.7$ & $16.4 \pm 0.4$ & $16 \cdot 4 \pm 0.3$ \\
\hline Pentaenoic & $I \cdot 4 \pm 0.2$ & $2.9 \pm 0.1$ & $I \cdot 7 \pm 0.1$ & $I \cdot 9 \pm 0 \cdot I$ \\
\hline Hexaenoic & $3.0 \pm 0.2$ & $3.9 \pm 0.2$ & II.0 \pm 0.3 & $10.8 \pm 0.6$ \\
\hline
\end{tabular}



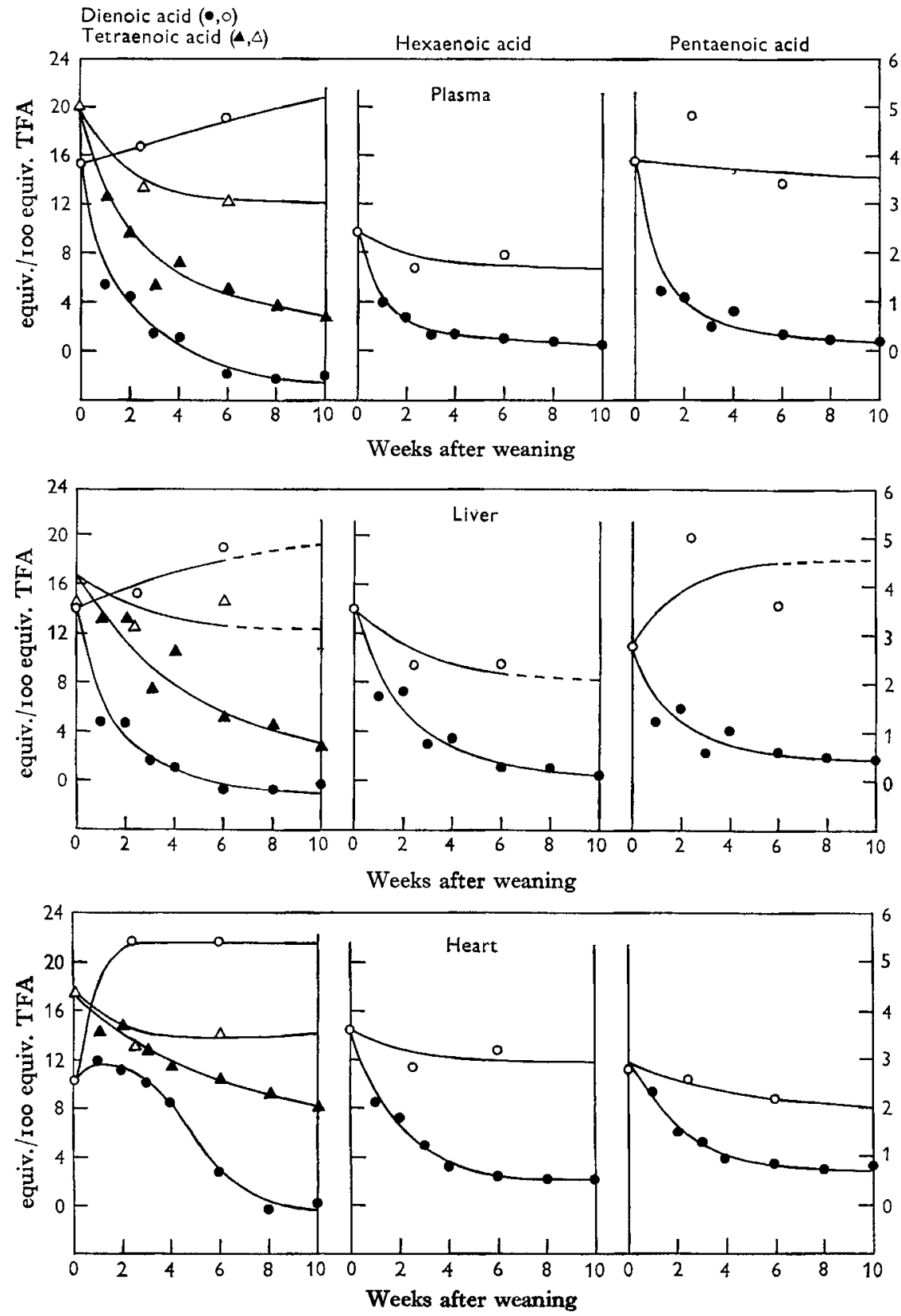

Fig. 3. Mean concentrations of polyenoic acids in rats fed on a fat-free diet $(\boldsymbol{O}$ and $\boldsymbol{\Delta}$ ) for up to Io weeks or on the stock diet $(O$ and $\triangle$ ) for up to 6 weeks after weaning. The scale on the right ordinate is for pentaenoic acid, that on the left for di-, tetra- and hexa-enoic acids. TFA, total fatty acids.

I week or less. Tetraenoic acid concentration apparently was the least affected. In relation to the controls, all the concentrations of polyenoic acids mentioned showed a progressive decrease with time. 
The concentration of trienoic acid expressed as equiv./ roo equiv. TFA increased proportionally with time during the first 4 (liver) or 6 (plasma, heart) weeks in the deficient animals, as shown in Fig. 4. In the controls only very small amounts of trienoic acid were present. The fall in trienoic acid concentration (equiv./100 equiv. TFA) observed in livers after 6 weeks was presumably due to dilution with increased amounts of more saturated acids. The concentration expressed as m-equiv. $/ \mathrm{kg}$ tissue increased proportionally with time for plasma, liver and heart during the first 6 weeks, and no fall in liver trienoic acid concentration was observed. The regression coeffcients (Snedecor, 1956) for the regression of trienoic acid concentration on time are given in Table 7 .
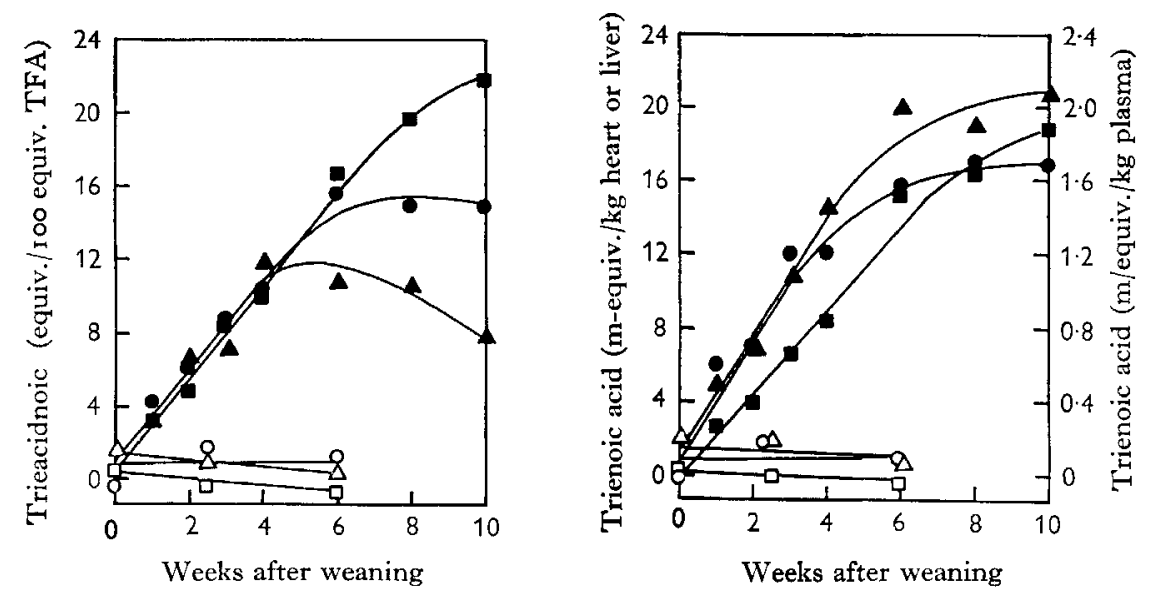

Fig. 4. Mean concentration of trienoic acid in plasma (O), liver (A) and heart $(\boldsymbol{\square})$ of rats fed on a fat-free diet for up to ro weeks after weaning. Open symbols, rats fed on the stock diet for up to 6 weeks; TFA, total fatty acids.

Table 7. Regression coefficients $\left(b \pm s_{b}\right)$ for the regression of trienoic acid concentration on time (weeks) for rats fed on the fat-free diet for up to 6 weeks after weaning

$\begin{array}{lcc}\text { Tissue } & \overbrace{\text { Equiv./roo equiv. TFA }}^{\text {Trienoic acid concentration }} \\ \text { Plasma } & 2.55 \pm 0.16 & \text { m-equiv./kg tissue } \\ \text { Liver } & 2.38 \pm 0.3 \mathrm{I}^{*} & 0.255 \pm 0.039 \\ \text { Heart } & 2.65 \pm 0.13 & 3.04 \pm 0.12 \\ & 2.38 \pm 0.02\end{array}$

TFA, total fatty acids.

* Observation period 4 weeks.

\section{DISCUSSION}

Weight gain. In agreement with the findings of a number of investigators, e.g. Peifer \& Holman (1959), the difference in body-weight between the normal and deficient animals was negligible during the first 3 weeks. The difference increased with the time on the diet, and after about Io weeks the body-weight of the deficient rats reached a plateau at about $25^{\circ} \mathrm{g}$, which is similar to the observations by a number of investigators (e.g. Alfin-Slater, Aftergood, Bingemann, Kryder \& Deuel, I957; 
Christensen, Dam \& Engel, 1957; Privett, Aaes-Jørgensen, Holman \& Lundberg, 1959; Mattson, x960).

The weights of the liver and heart were apparently unaffected by the deficiency during the first 6 weeks (Fig. 2). Similar observations have been made by Kaunitz, Slanetz, Johnson \& Babayan (1960), who fed rats on a fat-free diet and on the same diet supplemented with $2 \%$ linoleic acid. After $\mathbf{2} 2$ weeks the animals receiving linoleic acid weighed $40 \%$ more than the deficient ones, whereas their livers and hearts weighed only 10 \% more. The same tendency is seen in the results of Barnes, Tuthill, Kwong \& Fiala (1959) after 8 weeks of feeding. In this connexion it should likewise

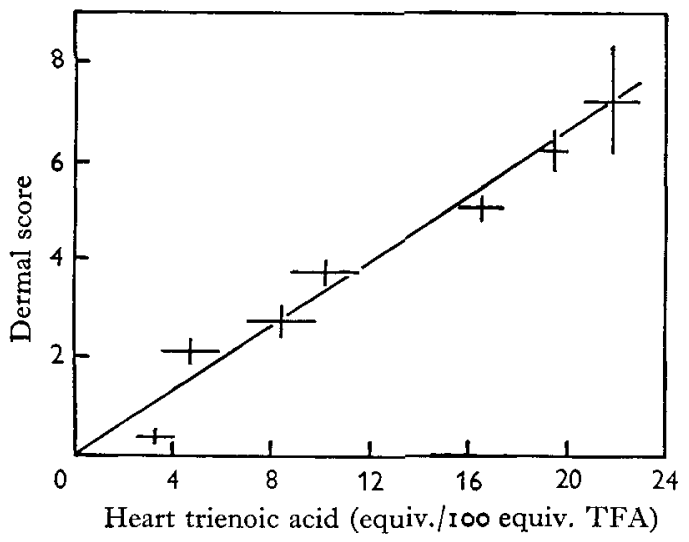

Fig. 5

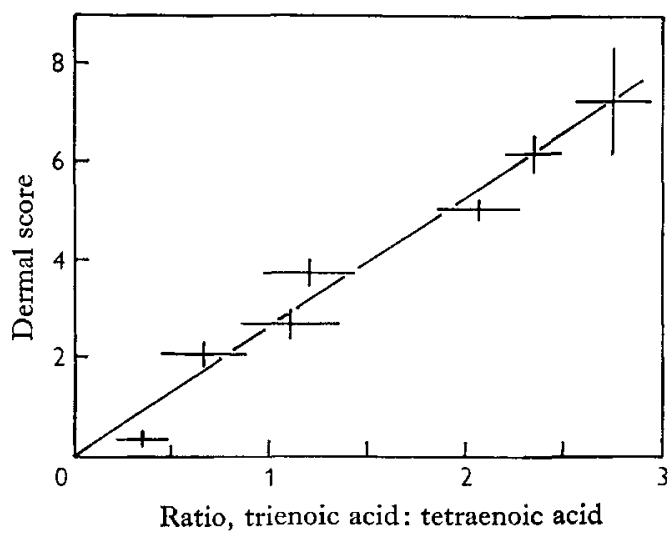

Fig. 6

Fig. 5. Relation between dermal score (see p. 2 I I) and heart trienoic acid concentration for rats fed on a fat-free diet for up to ro weeks after weaning. Mean values with their standard errors. TFA, total fatty acids.

Fig. 6. Relation between dermal score (see p. $2 \mathrm{rI}$ ) and the ratio of liver concentrations of trienoic to tetraenoic acids for rats fed on the fat-free diet for up to ro weeks after weaning. Mean values with their standard errors.

be mentioned that Alfin-Slater, Aftergood, Wells \& Deuel (1954) found that the liver weight, expressed as a percentage of body-weight, was considerably higher for deficient adult rats than for normal rats of the same age. Further, it has been observed that the weight of the testes after 9 weeks was the same for normal as for EFAdeficient rats (Panos, Klein \& Finerty, I959).

All these observations seem to indicate that EFA deficiency has a greater influence on body-weight than on the weight of the organs. The difference in body-weight may be due to a difference in the amount of depot fat, deficient rats having little or no depot fat (cf. Burr \& Burr, 1929). However, this is presumably not the only cause inasmuch as Alfin-Slater \& Bernick (1958) have reported the finding of a reduced number of proliferating cells in the bone of EFA-deficient rats after 12 weeks.

Dermal signs. The comparison of dermal scores observed in different laboratories is usually considered to be of little value, partly because the grading is based on a subjective estimate, and partly because the severity of dermal signs is dependent on the humidity (Brown \& Burr, 1936). In the experiment presented here, the dermal 
score after Io weeks was $7 \cdot 25$, or about $60 \%$ of the maximal value of 12 . This is in excellent agreement with the results of Privett et al. (1959) (50-66\% after II weeks) and those of Privett, Pusch, Holman \& Lundberg (1960) (75\% after I 4 or I6 weeks).

The dermal score was proportional to time for the first $5^{-6}$ weeks, in agreement with the results of Holman \& Peifer (1960). In the experiment presented here it was furthermore found that this score (mean for all animals) was proportional to group means of heart trienoic acid concentration (Fig. 5) and to the ratio between the concentrations of trienoic and tetraenoic acids in liver (Fig. 6); the last-mentioned ratio has been used by Holman (1960) as a measure of the EFA status of rats. Furthermore, a linear relationship showing a negative correlation between dermal score and heart dienoic +

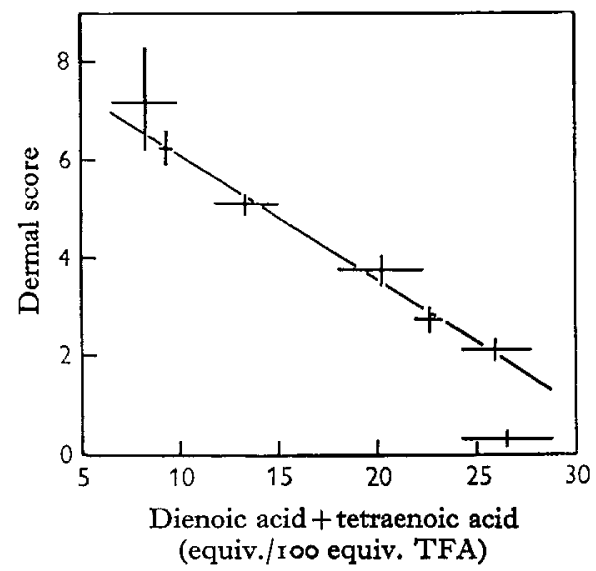

Fig. 7. Relation between dermal score (see p. $2 \mathrm{II}$ ) and the sum of the concentrations of dienoic and tetraenoic acids in the hearts of rats fed on the fat-free diet for up to ro weeks after weaning. Mean values with their standard errors. TFA, total fatty acids.

tetraenoic acid concentration (equiv./100 equiv. TFA) as shown in Fig. 7 was seen. These observations suggest but do not prove that the dermal score under certain experimental conditions might be used as a quantitative indicator of the EFA status in rats.

Cholesterol and total fatty acids. From Table 4 it is apparent that there was an accumulation of cholesterol and fatty acids in the livers of the deficient rats.

Further, the following equations, based on the individual liver concentrations of cholesterol and TFA for all animals in groups I-IO, demonstrate a rectilinear relationship between the two quantities:

$$
\begin{aligned}
& \text { Cholesterol }(\mathrm{mg} / \mathrm{Io0} \mathrm{g})=(\mathrm{r} \cdot 96 \pm 0 \cdot \mathrm{I} 5) \times \mathrm{TFA}(\mathrm{m} \text {-equiv. } / \mathrm{kg})+67 \cdot 5 \\
& \text { Cholesterol }(\mathrm{m}-\mathrm{mole} / \mathrm{kg})=(0 \cdot 0507 \pm 0 \cdot 0040) \times \mathrm{TFA}(\mathrm{m} \text {-equiv. } / \mathrm{kg})+\mathrm{I} \cdot 75
\end{aligned}
$$

It is seen that the increase in the molar concentration of TFA is about twenty times that of the cholesterol concentration.

An increase in the concentration of cholesterol esters has previously been observed in the liver of young deficient rats by Klein (1958) and by Mukherjee, Achaya, Deuel \& Alfin-Slater (1958) and in adult deficient rats by Alfin-Slater et al. (1954). From the 
data of Nath, Wiener, Harper \& Elvehjem (1959) it appears that after Io weeks of deficiency the amounts of cholesterol, phospholipids and total fat were greater in the livers of deficient rats than in those of normal rats by 60,5 and $2200 \mathrm{mg} / \mathrm{ro0} \mathrm{g}$ liver respectively, indicating that also in their experiment the accumulation of triglycerides was the most pronounced.

The reason for this accumulation of liver lipids is not clear. According to Mukherjee \& Alfin-Slater (1958) and Merril (1959), the hepatic metabolism of cholesterol is decreased in the deficient rat, but Klein (1958) has shown that the accumulation of cholesterol esters is not systematically related to either the linoleic acid content of the diet or the polyenoic fatty acid composition of liver cholesterol esters. According to Klein (1958), the liver concentration of free cholesterol ( $\mathrm{mg} / \mathrm{roog}$ ), which in the normal animal is about $70 \%$ of that of total cholesterol, does not change in EFA deficiency. In the animals in group o, $\mathrm{C}_{2} \frac{1}{2}$ and $\mathrm{C} 6$ of the experiment presented here, $70 \%$ of the total cholesterol concentration was equal to $180 \mathrm{mg} / \mathrm{I} 00 \mathrm{~g}$ liver; assuming that this corresponds to free cholesterol, the concentration of cholesterol esters was that of total cholesterol minus $180 \mathrm{mg} / \mathrm{l} 00 \mathrm{~g}$ liver. It could now be demonstrated that the concentration of cholesterol esters $(Y \mathrm{mg} / \mathrm{ro0} \mathrm{g}$ liver) was very nearly inversely proportional to the tetraenoic acid concentration ( $\mathrm{I} / X$, equiv./Ioo equiv. TFA): $Y=\left(I_{5} \pm 7 \mathrm{I}\right) \times X+\mathrm{I} 2 \cdot 8$. This might indicate that the metabolism of cholesterol esters is systematically related to the polyenoic acid pattern in the liver.

The observation that the deficient rats had higher plasma cholesterol concentrations than the controls does not find confirmation in the literature. On the contrary, a number of workers (Alfin-Slater et al. 1954; Klein, 1958; Barnes et al. 1959; Brenner et al. 1962) have reported values for plasma cholesterol showing the reverse relationship. The explanation for this deviation is not clear. It should be mentioned that deficiency in EFA leads to hypercholesterolaemia in rats fed on a hypercholesterolaemic diet (Quackenbush \& Pawlowski, I960), in chickens (Hølmer, Kristensen, Søndergaard \& Dam, 1960) and in rabbits (Malmros \& Wigand, 1959).

Polyenoic acids. The concentrations of the various polyenoic acids in the control rats changed slowly with time on diet except for heart dienoic acid, the concentration of which increased by $100 \%$ during the first $2-2 \frac{1}{2}$ weeks, after which it remained constant. In agreement with this observation, Aaes-Jørgensen \& Holman (1958) and Kirschman \& Coniglio (I96I) have found that in normal rats, $3^{-6}$ months old, the concentration of heart dienoic acid is about twice that in weanling rats.

In the deficient rats the concentrations of di-, tetra-, penta- and hexa-enoic acids decreased regularly with time except for heart dienoic acid (Fig. 3). In this instance the rapid increase in the controls was reflected in the 'concentration versus time curve' of the deficient rats, which naturally complicates the direct comparison between the changes in polyenoic acid concentrations in the various tissues. It was therefore thought that for such comparisons it would be useful to express the group means for polyenoic acid concentration in the deficient rats as percentages of the corresponding values for the control rats. This value is termed the relative concentration.

From the semi-logarithmic graphical representation in Fig. 8 it appears that the decrease with time in the relative concentration (calculated from equiv./roo equiv. 
TFA values) of di- and tetra-enoic acids, for at least 6 weeks of deficiency, followed a first-order equation. For penta- and hexa-enoic acids the curves probably have two slopes. When the relative concentrations were calculated from the concentrations in m-equiv./kg tissue, generally the same picture was found. The regression coefficients

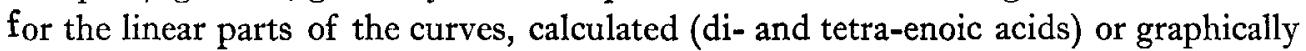
determined (penta- and hexa-enoic acids) are given in Fig. 8. From these regression
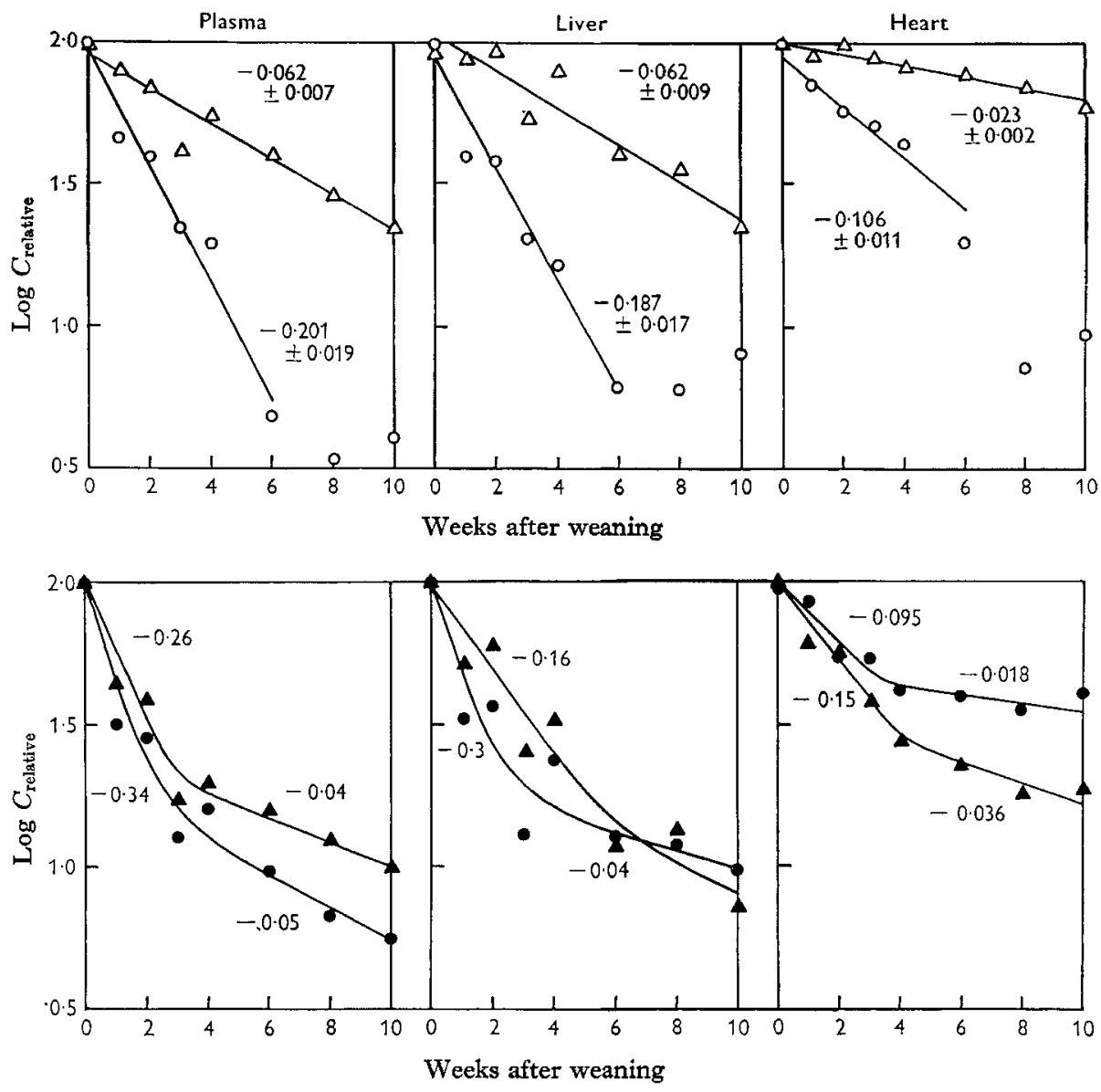

Fig. 8. Relations between the relative concentrations of dienoic $(O)$, tetraenoic $(\triangle)$, pentaenoic $(\odot)$ and hexaenoic $(\Delta)$ acids and time on experiment for rats fed on the fat-free diet for up to ro weeks after weaning. The ordinate of each point was calculated as

$$
\log C_{\text {relettve }}=\log \frac{\text { group mean of polyenoic acid conc., deficient rats }}{\text { polyenoic acid conc., control rats }} \times 100,
$$

all concentrations being expressed as equiv./100 equiv. total fatty acids. The calculated (dienoic and tetraenoic acids) or graphically determined (pentaenoic and hexaenoic acids) regression coefficients of the linear parts are given on the figure.

coefficients it is possible to determine the time required for the concentration of a polyenoic acid in the deficient rats to reach $50 \%$ of that in the control rats. This value is here termed the 'relative half-time'. An analogous expression: 'half-time of 
depletion' has been used by Ostwald, Okey, Shannon \& Tinoco (1962), who expressed the concentration as a percentage of the value at zero time.

The relative half-times calculated as described are given in Table 8 . It will be seen that the values for dienoic acid and for the first slopes of penta- and hexa-enoic acids are of the same order of magnitude, and so are the values for tetraenoic acid and for the second slopes of penta- and hexa-enoic acids. Further, the relative half-time for a given acid is similar for plasma and liver, except for the second slopes of penta- and hexa-enoic acids in terms of m-equiv. $/ \mathrm{kg}$, whereas for heart tissue it is generally considerably higher. This finding - in connexion with the observations of Rieckehoff, Holman \& Burr (1949) and of Widmer \& Holman (1950) that the deposition of dietary polyenoic acids was most pronounced in the heart of the deficient rat-seems to indicate that heart tissue has a relatively great capacity for retaining these acids.

The biological interpretation of the relative half-time cannot be elucidated on the basis of the experiment presented here. It is, however, of interest to note that the relative half-times of dienoic, pentaenoic and hexaenoic acids (which are probably not synthesized in the deficient rat) are similar to the value $14.9 \pm 0.15$ days for the halflife of total body fat in $15 \circ \mathrm{g}$ rats (Matthews, Spector, Lemm \& Olynyk, 1957). Likewise, for rats weighing about $300 \mathrm{~g}$, Bates, Mayer \& Nauss (1955) found the half-life of total body fat to be $18 \pm 4$ days, and Phil, Bloch \& Anker (1950) determined the half-life of saturated fatty acids to be about 16 days.

Table 8. Time (days) required for the concentration of a polyenoic acid in the deficient rats to reach $50 \%$ of that in the control rats (the 'relative half-time'*)

\begin{tabular}{|c|c|c|c|c|c|c|}
\hline \multirow[b]{3}{*}{ Tissue } & \multicolumn{6}{|c|}{ Polyenoic acid } \\
\hline & \multirow[b]{2}{*}{ Dienoict } & \multirow[b]{2}{*}{ Tetraenoic $\dagger$} & \multicolumn{2}{|c|}{ Pentaenoic } & \multicolumn{2}{|c|}{ Hexaenoic } \\
\hline & & & $\begin{array}{l}\text { First } \\
\text { slope }\end{array}$ & $\begin{array}{l}\text { Second } \\
\text { slope }\end{array}$ & $\begin{array}{l}\text { First } \\
\text { slope }\end{array}$ & $\begin{array}{l}\text { Second } \\
\text { slope }\end{array}$ \\
\hline \multicolumn{7}{|c|}{ equiv./roo equiv. TFA } \\
\hline Plasma & $10 \cdot 5 \pm 1 \cdot 5$ & $34 \pm 4$ & 6 & 40 & 8 & 50 \\
\hline Liver & $I I \cdot 3 \pm I \cdot I$ & $34 \pm 5$ & 7 & 50 & 13 & - \\
\hline Heart & $20 \cdot 0 \pm 2 \cdot 0$ & $92 \pm 8$ & 22 & 120 & I4 & 60 \\
\hline \multicolumn{7}{|c|}{ m-equiv./kg tissue } \\
\hline Plasma & $10 \cdot 5 \pm 1 \cdot 2$ & $39 \pm 4$ & 13 & 34 & I3 & 53 \\
\hline Liver & $I r \cdot 4 \pm x \cdot 0$ & $58 \pm 7$ & 9 & 120 & 12 & 120 \\
\hline Heart & $21 \cdot 8 \pm 2 \cdot 0$ & $149 \pm 35$ & 25 & 85 & I6 & 200 \\
\hline
\end{tabular}

Further, in a study concerning the kinetics of linoleic acid depletion Tove \& Smith (1959) found a half-life of about 9 days for linoleic acid in carcass fat in mice fed on a fat-free diet from 3 weeks of age. This value is very close to the relative half-time for dienoic acid in plasma and liver given in the present communication.

The trienoic acid, the concentration of which increased during deficiency (Fig. 4), is $5,8, \mathrm{II}$-eicosatrienoic acid synthesized from oleic acid in the EFA-deficient rat 
(Fulco \& Mead, I959). Bozian \& Coniglio (I962) have suggested that arachidonic acid may function as a regulator of this conversion and this is also the conclusion of Peluffo, Brenner \& Mercuri (1963). However, from the experiments of Mohrhauer \& Holman (I963) it appears that dietary linolenate depresses the trienoic acid concentration without increasing the concentration of arachidonic acid. From the present paper it is evident that, although the rates of decrease of the concentration of di-, tetra-, penta- and hexa-enoic acids in the plasma and liver were different from the corresponding rates of decrease of these acids in the heart (Fig. 8, Table 8), the concentration (equiv./ roo equiv. TFA) of trienoic acid increased at the same rate for all these tissues during the first 4 weeks (Fig. 4 and Table 7). From this finding it may be inferred that, if trienoic acid accumulation is regulated specifically by the concentration of one or other type of polyenoic acid, then the response, expressed as increase in trienoic acid concentration, apparently is different in different tissues.

From the results presented here, it will be seen that the difference in polyenoic acid concentration between the controls and the deficient animals increased rapidly during the first weeks, but slowly after $4-6$ weeks of feeding, and that changes were generally more pronounced in plasma and liver than in heart tissue. These observations suggest that, in studies concerning the influence of dietary factors on the polyenoic acid pattern of weanling rats, an experimental period of about 6 weeks would be sufficient, especially if the study were confined to plasma and liver tissue.

\section{SUMMARY}

I. Weanling male rats were reared on either a fat-free diet for up to to weeks (deficient) or on a stock diet for up to 6 weeks (control). At weekly or biweekly intervals three to five rats were killed and the concentrations of cholesterol, total fatty acids and polyenoic acids were measured in their plasma, liver and heart. Further, the weights of body, heart and liver as well as the dermal signs of deficiency of essential fatty acids were recorded.

2. The mean growth rate, as measured by body-weight, was lower for deficient than for control animals. The weight of liver or heart during the first 6 weeks was, however, independent of the diet.

3. The EFA-deficiency signs, expressed as a dermal score, increased proportionally with time for the first $5-6$ weeks. Further, the dermal score was found to be related to the fatty acid pattern in that it was proportional to heart trienoic acid concentration, to the ratio between trienoic and tetraenoic acid concentration in the liver, and negatively correlated to heart dienoic + tetraenoic acid concentration.

4. In the livers of the deficient animals the concentration of cholesterol and TFA increased with time. The concentration of cholesterol ester was inversely proportional to the tetraenoic acid concentration.

5. In the control rats the dienoic acid concentration in plasma and liver increased slowly with time. In heart tissue, however, it was doubled within 2 weeks after weaning, after which it remained constant. The concentrations of the other polyenoic acids generally decreased slightly during the first weeks. 
6. After only I week on the fat-free diet, the fatty acid pattern of deficient rats was different from that of the controls. The relative concentration (the concentration of a polyenoic acid in deficient rats as a percentage of the corresponding concentration in control rats) for dienoic and tetraenoic acids was related to time by a first-order equation, whereas the semi-logarithmic graphical representations of the relative concentrations of penta- and hexa-enoic acids had two slopes.

7. The 'relative half-times', calculated from the first-order rate constants of the above-mentioned equations, were similar for plasma and liver but higher for heart tissue. The plasma and liver values for dienoic, pentaenoic and hexaenoic acids (6-I3 days) were of the same order of magnitude as the half-life found by others for total body fat, for saturated fatty acids in rats or for linoleic acid in carcass fat of mice.

8. The concentration of trienoic acid (equiv./roo equiv. TFA) increased at the same rate in plasma, liver and heart in the deficient rats for the first $4-6$ weeks. The factor(s) responsible for the trienoic acid accumulation are discussed.

9. The results suggest that the biochemical response to EFA deficiency is most pronounced in plasma and liver. In experiments with weanling rats an experimental period of about 6 weeks would be sufficient, since the majority of the changes in the fatty acid pattern take place during this period.

This work was partly financed by a grant from the Butter Information Council, UK. I am greatly indebted to Mrs Grete Nørby and Mrs Wenche Berg Johannessen for skilled technical assistance.

\section{REFERENCES}

Aaes-Jørgensen, E. \& Holman, R. T. (1958). F. Nutr. 65, 633.

Alfin-Slater, R. B., Aftergood, L., Bingemann, L., Kryder, G. D. \& Deuel, H. J. Jr. (r957). Proc. Soc. exp. Biol., N.Y., 95, 521 .

Alfin-Slater, R. B., Aftergood, L., Wells, A. F. \& Deuel, H. J. Jr. (1954). Arch. Biochem. Biophys. 52, I80.

Alfin-Slater, R. B. \& Bernick, S. (1958). Amer. F. clin. Nutr. 6, 6r3.

Barnes, R. H., Tuthill, S., Kwong, E. \& Fiala, G. (1959). F. Nutr. 68, 12r.

Bates, M. W., Mayer, J. \& Nauss, S. F. (1955). Amer. F. Physiol. 180, 309.

Bozian, R. C. \& Coniglio, J. G. (1962). Fed. Proc. 21, 286.

Brenner, R. R., Mercuri, O. \& De Tomás, M. E. (I962). F. Nutr. 77, 203.

Brown, W. R. \& Burr, G. O. (1936). F. biol. Chem. Ir4, xvi.

Burr, G. O. \& Burr, M. M. (1929). F. biol. Chem. 82, 345.

Caster, W. O. \& Holman, R. T. (r961), F. Nutr. 73, 337.

Christensen, F., Dam, H. \& Engel, P. F. (1957). Acta physiol. scand. 38, 373.

Fulco, A. J. \& Mead, J. F. (1959). F. biol. Chem. 234, 14 I I.

Hauge, J. G. \& Nicolaysen, R. (1958). Acta physiol. scand. 43, 359.

Hawk, P. B. \& Bergeim, O. (I937). Practical Physiological Chemistry, I Ith ed., p. 887 . Philadelphia: P. Blakiston's Son \& Co. Inc.

Herb, S. F. \& Riemenschneider, R. W. (1953). Analyt. Chem. 25, 953.

Holman, R. T. (1956). Svensk kem. Tidskr. 68, 282.

Holman, R. T. (1960). F. Nutr. 70, 405.

Holman, R. T. \& Peifer, J. J. (I960). Ұ. Nutr. 70, 4 I I.

Hølmer, G., Kristensen, G., Søndergaard, E. \& Dam, H. (1960). Brit. F. Nutr. 14, 247.

Kaunitz, H., Slanetz, C. A., Johnson, R. E. \& Babayan, V. K. (I960). F. Nutr. 7I, 400.

Kirschman, J. C. \& Coniglio, J. G. (196I). Arch. Biochem. Biophys. 93, 297.

Klein, P. D. (1958). Arch. Biochem. Biophys. 76, 56.

Machlin, L. J. (1961). Proc. Soc. exp. Biol., N.Y., 108, 819.

Malmros, H. \& Wigand, G. (1959). Lancet, ii, 749.

Matthews, LeR. W., Spector, S., Lemm, J. \& Olynyk, P. (1957). Amer. F. Physiol. 188, 308. 
Mattson, F. H. (1960). F. Nutr. 7r, 366.

Merril, J. M. (1959). Circ. Res. 7, 709.

Mohrhauer, H. \& Holman, R. T. (1963). F. Lipid Res. 4, I 51.

Montag, W., Klenk, E., Hayes, H. \& Holman, R. T. (r957). F. biol. Chem. 227, 53.

Mukherjee, S., Achaya, K. T., Deuel, H. J. Jr. \& Alfin-Slater, R. B. (1958). F. Nutr. 65, 469.

Mukherjee, S. \& Alfin-Slater, R. B. (1958). Arch. Biochem. Biophys. 73, 359.

Nath, N., Wiener, R., Harper, A. E. \& Elvehjem, C. A. (1959). F. Nutr. 67, 289.

Narby, J. G. (I96I). Acta chem. scand. 15, 525.

Nørby, J. G. (1965). Brit. F. Nutr. r9, 35.

Ostwald, R., Okey, R., Shannon, A. \& Tinoco, J. (I962). $\mathscr{f} . ~ N u t r .76,34$ r.

Panos, T. C., Klein, G. F. \& Finerty, J. C. (1959). F. Nutr. 68, 509.

Peifer, J. J. \& Holman, R. T. (1959). F. Nutr. 68, I 55.

Peluffo, R. O., Brenner, R. R. \& Mercuri, O. (1963). F. Nutr. 8I, I ro.

Phil, A., Bloch, K. \& Anker, H. S. (1950). F. biol. Chem. r83, 441.

Privett, O. S., Aaes-Jørgensen, E., Holman, R. T. \& Lundberg, W. O. (1959). F. Nutr. 67, 423.

Privett, O. S., Pusch, F. J., Holman, R. T. \& Lundberg, W. O. (1960). F. Nutr. 71, 66.

Quackenbush, F. W. \& Pawlowski, M. D. (1960). F. Nutr. 72, 196.

Rieckehoff, I. G., Holman, R. T. \& Burr, G. O. (1949). Arch. Biochem. 20, 331.

Snedecor, G. W. (1956). Statistical Methods, 5th ed., p. 122. Ames, Iowa: The Iowa State University Press.

Tove, S. B. \& Smith, F. H. (1959). Arch. Biochem. Biophys. 85, 352.

Widmer, C. Jr. \& Holman, R. T. (I950). Arch. Biochem. 25, I. 